\title{
OVERVIEW
}

\section{Inflation Targeting dan Penerapan Otonomi Daerah}

\author{
Siti Astiyah*
}

Studi yang telah dilakukan menunjukkan bahwa hubungan antara besaran-besaran moneter (uang beredar) dengan sasaran akhir kebijakan moneter makin melemah di Indonesia ${ }^{1}$, sehingga timbul keraguan mengenai efektivitas kebijakan moneter dalam mencapai sasaran akhir dengan menggunakan besaran moneter sebagai intermediate target. Disamping itu, sejak Agustus 1997, batas intervensi nilai tukar telah dihapus. Maka dirasa perlu untuk mencari nominal anchor baru dari kebijakan moneter, dan kecenderungan di banyak negara mengarah ke eksplisit sasaran inflasi atau yang lebih dikenal dengan inflation targeting. Dalam inflation targeting, sasaran akhir kebijakan moneter diarahkan untuk mencapai tingkat inflasi yang relatif rendah dan stabil ${ }^{2}$.

Salah satu hal penting dalam inflation targeting adalah adanya penyampaian target inflasi yang akan dicapai oleh bank sentral dalam suatu periode tertentu kepada publik ${ }^{3}$. Penyampaian target inflasi ini mempunyai peranan yang penting didalam regim inflation targeting karena hal tersebut dapat membantu publik untuk menentukan ekspektasi inflasi dan juga dapat dipakai sebagai dasar untuk menilai kinerja dari bank sentral untuk mencapai target akhir dari kebijakan moneternya ${ }^{4}$. Keberhasilan bank sentral dalam mencapai target

* Peneliti Ekonomi Yunior di Bagian Analisis dan Perencanaan Kebijakan, Bank Indonesia

1 Antara lain studi yang dilakukan oleh APK/DKM(2002) untuk PKS Juni 2002 (mendatang) mengenai pengembangan program moneter dalam kerangka inflation targeting.

2 Fokus sasaran akhir kebijakan moneter pada inflasi sesuai dengan amanat UU no.23 tahun 1999 tentang Bank Indonesia. UU tersebut mengamanatkan bahwa tujuan dari kebijakan moneter Bank Indonesia untuk mencapai dan mempertahankan stabilitas nilai mata uang rupiah. Untuk mencapai stabilitas rupiah tersebut maka tujuan dari kebijakan moneter diarahkan untuk mencapai tingkat inflasi yang relatif rendah dan stabil.

3 Penyampain target inflasi ke publik dilakukan oleh pemerintah (antara lain: Brazil, Israel, dan Inggris), disampaikan oleh bank sentral (antara lain: Chili, Finlandia, Polandia, Spanyol, dan Swedia), disampaikan oleh pemerintah dan bank sentral (antara lain: Australia dan New Zealand).

4 Karena tingkat inflasi juga dipengaruhi oleh faktor lain yang tidak dapat dipengaruhi oleh kebijakan moneter (misalkan external shock) maka kemampuan kebijakan moneter untuk mencapai tingkat inflasi tersebut juga harus disesuaikan yaitu inflasi yang sudah disesuaikan dengan caveatable items atau seringkali disebut sebagai inflasi inti (core atau underlying inflation). Sehingga keberhasilan bank sentral untuk mencapai target inflasi tidak ditentukan oleh inflasi yang dihitung dari indeks harga konsumen (selanjutnya disingkat dengan inflasi IHK) tetapi IHK setelah disesuaikan dengan caveatable items tersebut. 
inflasi tersebut diharapkan dapat meningkatkan akuntabilitas bank sentral sebagai otoritas moneter. Masalah yang muncul adalah ukuran inflasi yang manakah yang menjadi tolok ukur untuk menilai keberhasilan kebijakan moneter bank sentral karena tidak semua gejolak inflasi dapat diselesaikan oleh kebijakan moneter. Inflasi yang diakibatkan oleh kebijakan kenaikan harga oleh pemerintah, gangguan alam, dan gejolak yang bersifat random lainnya berada diluar kontrol bank sentral, sehingga didalam literatur tanggung jawab bank sentral seringkali terbatas pada inflasi yang dapat dikontrol oleh kebijakan moneter atau seringkali disebut inflasi inti (core atau underlying inflation). Inflasi inti inilah yang merupakan fenomena moneter. Akan tetapi karena ukuran inflasi inti ini kurang populer di masyarakat dibandingkan dengan ukuran inflasi IHK, maka banyak bank sentral menggunakan inflasi IHK sebagai target akhir kebijakan moneternya ${ }^{5}$. Masalah yang muncul adalah seberapa jauh kebijakan moneter dapat efektif untuk mencapai target inflasi IHK?. Hal ini disebabkan banyak items didalam inflasi IHK yang tidak dapat dikontrol oleh kebijakan moneter terutama dalam masa proses pemulihan ekonomi seperti di Indonesia.

Proses pemulihan ekonomi yang masih berlangsung sekarang ini meminta ongkos yang sangat tinggi untuk masyarakat banyak dan hal ini menambah tekanan inflasi, misalnya tekanan dari sektor fiskal untuk menghilangkan subsidi berperan meningkatkan harga; namun kenaikan harga yang disebabkan oleh kebijakan tersebut tidak dapat diselesaikan oleh kebijakan moneter. Inflation shock yang mungkin banyak timbul selama proses pemulihan ekonomi tersebut harus diperhitungkan dalam penentuan target inflasi dan hal ini merupakan tantangan yang harus dihadapi oleh bank sentral dalam penentuan target akhir kebijakan moneternya. Tantangan lain yang mungkin juga harus diperhitungkan dalam pencapaian target akhir adalah penerapan otonomi daerah.

Sejak 1 Januari 2001 telah dilaksanakan otonomi daerah sebagaimana tertuang dalam UU nomor 22 dan 25 tahun 1999 tentang pemerintah daerah dan perimbangan keuangan pemerintah pusat dan daerah. Dengan diimplementasikannya kedua UU tersebut dan peraturan-peraturan yang melengkapinya maka diharapkan berimplikasi positip terhadap peningkatan ekonomi dan pendapatan daerah ${ }^{6}$. Munculnya dana perimbangan ${ }^{7}$ dalam pendapatan daerah berperan penting untuk meningkatkan pendapatan daerah secara substantial terutama bagi daerah-daerah yang memiliki sumber daya alam yang cukup. Akan tetapi adanya pembagian dana dan pelimpahan wewenang yang lebih besar kepada

5 Negara yang menggunakan inflasi IHK sebagai sasaran akhir kebijakan moneter antara lain: Brazil, Chili, Israel, New Zealand, dan Swedia. Sedangkan negara yang menggunakan inflasi inti sebagai sasaran akhir kebijakan moneter antara lain: Australia, Canada, Finlandia, dan Inggris.

6 Sumber pendapatan daerah menurut UU nomor 25 tahun 1999 antara lain: pendapatan asli daerah sendiri, dana perimbangan, pinjaman daerah, dan lain-lain pendapatan daerah yang sah.

7 Dana perimbangan terdiri dari dana bagi hasil, dana alokasi umum, dan dana alokasi khusus. Prosentase pembagian dana bagi hasil antara pemerintah pusat dan daerah telah diatur dalam pasal 7 dan 8 UU nomor 25 tahun 1999 tentang perimbangan keuangan antara pemerintah pusat dan daerah. 
daerah-daerah juga berpotensi untuk merubah perilaku fiskal daerah-daerah. Dari sisi moneter, perubahan perilaku tersebut kemungkinan berpengaruh terhadap pengendalian moneter maupun menambah tekanan inflasi.

Sejauh ini belum ada studi mengenai dampak otonomi daerah terutama perimbangan keuangan pemerintah pusat dan daerah terhadap inflasi di Indonesia. Akan tetapi dengan diimplementasikannya kedua UU tersebut maka perlu diperhatikan adanya potensi untuk menambah tekanan inflasi. Tekanan inflasi tersebut dapat berasal dari kemungkinan munculnya pengenaan atau kenaikan pajak daerah yang menjadi wewenang pemerintah daerah atau peningkatan pengeluaran daerah secara substantial. Peningkatan pengeluaran daerah bersifat positip jika diikuti alokasi pengeluaran ke sektor yang produktif sehingga akan berperan meningkatkan perekonomian daerah, akan tetapi jika pengeluaran tersebut bersifat tidak produktif maka hal tersebut akan berdampak menambah tekanan inflasi di daerah tersebut dan pada gilirannya akan berdampak menambah tekanan inflasi nasional. Disamping itu, salah satu pos lain-lain penerimaan daerah yang dianggap sah adalah pungutan daerah. Pengenaan pungutan daerah yang tidak wajar kemungkinan akan meningkatkan harga produk dari daerah tersebut dan hal ini selain mengurangi daya saing juga akan menambah tekanan inflasi. Adanya potensi dampak otonomi daerah dan desentralisasi fiskal terhadap tekanan inflasi, menjadi tantangan bagi bank sentral dalam menentukan target inflasinya.

Tantangan lain bagi bank sentral sehubungan dengan diterapkannya otonomi daerah dan desentralisasi fiskal adalah berkaitan dengan masalah pengendalian moneter dan studi tentang masalah ini telah dilakukan dan disajikan dalam edisi ini. Tantangan yang timbul dalam pengendalian moneter dikaitkan dengan kemampuan pemerintah daerah untuk memanfaatkan dana secara optimal dan produktif sehingga tidak menimbulkan dana yang menganggur (idle money). Apabila banyak dana yang menganggur maka hal ini berpotensi menambah uang primer. Peningkatan uang primer ini memberi tantangan bagi bank sentral dalam pengendalian moneternya dan kenaikan uang primer ini juga berpotensi menambah tekanan inflasi. Oleh karena itu, banyak tantangan menarik yang harus diperhatikan oleh Bank Indonesia didalam menentukan target inflasi secara wajar dalam situasi proses pemulihan ekonomi dan juga pelaksanaan otonomi daerah.

Buletin Ekonomi, Moneter dan Perbankan (BEMP) edisi ini mengetengahkan empat tulisan yang menarik untuk dibaca dan dapat digunakan sebagai masukan untuk penyusunan kerangka inflation targeting dalam proses pemulihan ekonomi dan era penerapan otonomi daerah dan desentralisasi fiskal secara komprehensif. Pada tulisan pertama, Susianto menganalisa secara teoritis penerapan inflation targeting dalam proses pemulihan ekonomi yang cenderung menciptakan inflation shock. Penulis menyatakan bahwa ada dua masalah yang harus dipertimbangkan dalam menerapkan inflation targeting dalam situasi 
pemulihan ekonomi. Pertama, menciptakan target inflasi yang kredibel yaitu sejauhmana model yang digunakan dalam menetapkan inflasi sudah memperhitungkan konsekuensi dari adanya proses pemulihan ekonomi. Kedua, sejauhmana komitmen pemerintah/bank sentral konsisten terhadap aturan main dalam pencapian target inflasi sehingga tidak tergoda untuk melakukan cheating. Selanjutnya ada beberapa model yang dapat dijadikan wacana untuk menetapkan target inflasi antara lain conservative dan non-conservative central bank.

Inflation targeting, dalam pelaksanaannya, membutuhkan suatu angka prediksi inflasi yang akurat dan untuk itu perlu adanya data yang baik. Namun masalahnya tidak semua data yang diperlukan tersedia dengan baik, salah satunya adalah data stok kapital. Untuk itu, pada tulisan kedua, Wicaksono et al menganalisa penghitungan data stok kapital dengan metode Perpetual Inventory (PIM). Pemilihan PIM dalam penghitungan stok kapital ini didasarkan atas pertimbangan biaya dan sumber daya manusia yang diperlukan relatif lebih sedikit dibandingkan dengan metode langsung (Direct Observation of Capital-DOC), namun karena sifatnya yang indirect maka akurasi dengan menggunakan PIM lebih rendah dibandingkan dengan DOC. Perhitungan stok kapital yang dilakukan oleh Wicaksonon et al ini telah memperhatikan kelemahan PIM dan untuk mengurangi kelemahan tersebut mereka menggunakan asumsi umur aset, pola distribusi, dan metode depresiasi lebih realistis dengan mengacu best practices dari negara lain yang menggunakan PIM. Selanjutnya dengan adanya penghitungan stok kapital yang baik maka diharapkan dapat diperoleh penghitungan output gap yang optimal sehingga dapat diketahui sumber tekanan inflasi.

Sementara itu, penerapan otonomi daerah kemungkinan juga berpengaruh menambah tekanan inflasi terutama dalam jangka pendek dan juga memberi tantangan terhadap pengendalian moneter. Dalam tulisan berikutnya, Ismal menganalisa dampak penerapan otonomi daerah khusunya alokasi dana perimbangan keuangan pusat dan daerah terhadap upaya pengendalian moneter selama tahun pertama penerapan otonomi daerah. Pelimpahan wewenang dan alokasi dana yang lebih besar kepada daerah berpotensi menimbulkan idle money, terutama dalam jangka pendek ini, dan hal ini memberikan tantangan kepada otoritas moneter dalam pengendalian moneter terutama dikaitkan dengan pengendalian uang primer.

Isu penting lainnya dalam edisi ini adalah membangun model yield curve untuk pasar obligasi di Indonesia yang dibahas secara komprehensif oleh Nurwadono dan Yunianto. Mereka membangun model yield curve obligasi pemerintah dengan menggunakan metode generalized bootstrap dan menggunakan bradley crane model untuk proses pemulusannya.

Selamat membaca. 